JEASP

Journal of English for Academic and Specific Purposes

Volume 3 Number 2, December, 2020

\title{
STUDENTS' READING BASED-MAIN IDEAS ON PASSAGES AT THE SECONDARY EDUCATION
}

\author{
Yogo Gandjarwati, M.Pd \\ (yogogandjarwati@gmail.com)
}

Sekolah Menengah Atas Negeri 1 Kauman

\begin{abstract}
ARTICLE
Keywords:

comprehending,

Passage,

Main Idea

ABSTRACT

Reading comprehension is crucial skill for both English as a Second Language (ELS) and English as a Foreign Language (EFL) students. To develop the students' reading ability, the use of main idea of paragraphs in comprehending the passage becomes an alternative solution to be used in teaching. This study is categorized as a Classroom Action Research (CAR). It was applied in use of main idea of paragraphs in comprehending the passage to improve the students' reading skills. The population of the study is 36 students at the second year students of SMAN 1 Kauman. The instruments of the study consisted of reading test and questionnaries. Based on the research finding that the students' reading skill and their motivation were still low, as it was indicated in pre-study, the score result was under KKM or the average score is 65,55 . Therefore, the researcher tried to apply the use of reading based main ideas on coomprehending passages to improve the reading skill. The writer found in the first cycle the average score is 77,00 . The next cycle done by the writer repaired the strategy in teaching reading through main idea of paragraphs. It was proved that the students' score average is 80,22. They passed and got the better score than previous result. It's concluded that the use of main idea of paragraphs in comprehending the passage was able to improve the students' reading skill. The students' interest in reading comprehension through main idea of paragraphs is also good. It has shown the result of questionnaire $(83,33 \%)$.
\end{abstract}

\section{INTRODUCTION}

Reading is a kind of practice to study a particular language. Richard and Renandya (2002:27) argued that reading has a special focus on foreign language learning in many circumstances. In other words, reading becomes a vital activity, which enables people to learn from a variety of texts in order to get enjoyment in finding work and dealing with such study purposes. Passage or text is a sequence of events or information consisting of topic, main idea and supporting sentences that each has integrated relationship. The main idea will be elaborated in detail so the reader can understand the 
JEASP

Journal of English for Academic and Specific Purposes

Volume 3 Number 2, December, 2020

information of text or passage easily (Burn \& Joyce, 2000, p. 45). The main idea also helps the readers grab the meaning of text well.

There are four English language skills students need to learn, such as listening, speaking, reading and writing. Almost people from many countries and around the world use both spoken and written English, which also includes reading. Reading is a necessary process for negotiating the context and making use of social awareness of the situation, the subject or the information point (Burn Joyce, 1999, p. 14). The object of reading is to grasp the context of the paragraphs of the text in the written language (Fahrurrazy, 2012, p.79). As members of society, we are usually taught to understand the passage, at least to understand the point in the chapters. However, there are reasons for why it is not enough to know how to write, and we are also interested in whether we should still know how to read the text as well. If we are able to read the text well, we will also have a better understanding of the other aspects of the passage. The knowledge of the main principle of paragraphs also helps one to grasp the entire information of a passage. When we can interpret the passage very well, we feel very satisfied and we know the content of the passage. The result of the information may be passed to someone else if it is desired (Zamel, 1987: 257).

Understanding the subject, gist or wider philosophical structure of a textbook chapter, essay, paragraph, sentence or passage is a sophisticated reading activity. The ability to draw conclusions, analyse and objectively view papers or chapters is crucial for the general understanding of college reading. Textbook chapters, posts, pages, sentences, or passages all have themes and key concepts. The theme is a broad, general theme or message. It is what some people call the subject. The core idea is to articulate the "key concept" Information, major and minor, reinforce the main concept by saying how when, where, where when, how many, and how many. Place of the subject, main premise, and supporting information helps you grasp the point(s) the writer is trying to make. Identifying the bond between them will improve the awareness. Fahrurrazy (1988: 32) identified both subject and key concept are important to the interpretation of the paragraphs.

This dynamic ability has a significant role to play in general reading comprehension. Instructions in key concept comprehension have been described as one of the teaching methods with the largest influence on reading comprehension by a variety of leading experts in the area. Key concept comprehension is also popular in educational activities (such as close reading and reading tests).

Teaching awareness with the use of the core concept of paragraph focuses on students' action, in which they need to realize what they are supposed to do. For example, before asking students to 
JEASP

Journal of English for Academic and Specific Purposes

Volume 3 Number 2, December, 2020

identify settings of a story, teachers should illustrate the setting based on time and place of the story. However, in case of understanding, teachers have been in a challenging situation from the start whey they attempt to identify a main idea of each paragraph reading for their students. The concept is extremely abstract, that is to clarify what main ideas entail without using the word 'main' and 'idea' in the description. Then, they turn the concept into a student whom will access its understanding, which shows difficulties that teachers face as they teach theoretical foundation of reading comprehension.

As a result of students' learning strategies to define the phrase 'main idea', the use of the first sentence of each first paragraph or the last paragraph works best to look at the concept of reading comprehension (Jacob, 2005, p.80).

\section{METHOD}

This research is the class action research held for one a half month, which focuses on basic competence of reading, Comprehending the passage through main idea of paragraphs. Before applying two cycles, the writer directly takes the result of previous reading test. The aim is that to compare the students' capability in comprehending the passage by using the ordinary way with the research technique (comprehending the passage through main idea of paragraphs). The class action research is held in two cycles to know the accurate result. The research implementation, in each cycle passes through the following steps.

\section{Cycle I (The First Month)}

The activities of the work plan:

Learning plan will be given to the students in the creation of assignments (work sheets)

\section{Implementation}

The writer gives the material about Reading.

She gives examples how to comprehend the passage through main idea of paragraph. The teacher gives an assignment related to reading and discussing with the students about the difficult task (dividing the member of the groups without noticing the level of the students' capability: excellent, ordinary, low) in each group. The students practiced finishing other assignments in a group. In another day the teacher gives a post test. In the post test, they try to finish the test individually based on some experiences got from the discussion with their friends before. 
JEASP

Journal of English for Academic and Specific Purposes

Volume 3 Number 2, December, 2020

\section{Cycle II (The Second Month)}

The activities of cycles $2 \mathrm{~s}$ the same as cycle 1. The additional is that It's done based on the result of reflection of the previous cycle. In this cycle also focuses on finishing reading tasks through main idea of paragraphs. The writer needs to identify participants whether they are more able to improve their reading skills. In relation to this reading development, the writer provides new textual contents by using similar approach to the cycle 1 in the way of steps to finish reading assignments through key concept of reading main ideas on first paragraphs in detail as follow:

a) distributing the reading material to students;

b) giving the revised way of comprehending passage through main idea of paragraphs in teaching learning process;

c) asking the students to finish writing assignment in a group to share opinions each other in doing it, and

d) giving other writing assignment and asking the students to finish individually based on their experiences from the discussion.

Based on the findings in the first cycle, the writer provides an additional step to resolve the weakness of the cycle 1. The writer divided students into groups of three to four students of whom are representatives to help other disadvantage students in a group to understand a main idea of a passage. At this point of students' group work, the writer spreads a questionnaire to document students' feedback. Understanding main ideas of first paragraphs can stimulate students' reading ability through doing assignments.

The sample population was observed in secondary education at SMAN 1 Kauman, particularly class XI IPA 2 (36 students) who are interested to be participants of this research. The writer found that students' experiences on reading passages using main ideas contribute to completing their reading tasks. By understanding passages in the use of main ideas, hopefully students will enable their cognitive language to understand passages easily.

The data analysis is quantitative data involving the data result of the reading tests. To get the score data related to comprehend the passage through main idea of paragraphs, which were taken from both (Test I) and (Test II). 
JEASP

Journal of English for Academic and Specific Purposes

Volume 3 Number 2, December, 2020

The formula of reading test

\section{Score $=$ Correct Answers $\mathrm{x} 4$}

Score is obtained from total number of test (25 items) times 4 . Since the writer knew students' curiosity in learning passages through the main ideas of passages in assignment completion, students were asked to fill out a questionnaire to identify whether reading maid ideas were easy or difficult. Students, then, provided feedback of their reading experiences on the following checklist.

Writing check list based on the students' interest in the column provided

finishing reading assignment related to comprehending the passage

No

Name

ordinary way

through main idea of paragraphs

\section{FINDINGS}

The writer carried out this research twice in cycle, which was relevant to students' reading tasks. The writer experimented students by providing two cycles supported by a questionnaire. Students, at first, read a passage and fulfilled their reading assignment both independently and in a group. Then, they filled out the questionnaire to tell their reading experience using main ideas on a passage. The writer noticed that this method enabled students to complete their reading task, and finally they provided feedback for what they did read a passage: reading a passage using a strategy of understanding its main ideas significantly help them find out reading problems. The result of the questionnaire was showed as follow. 
JEASP

Journal of English for Academic and Specific Purposes

Volume 3 Number 2, December, 2020

Table 1. The Result of Reading Test before Research (Pre-test)

The criteria of minimal success $=75$

The result of Pre-Test of Reading Test

\begin{tabular}{cccc} 
No & Range of Score & Total & Information \\
\hline 1 & $50-60$ & 10 & fail \\
\hline 2 & $61-70$ & 18 & fail \\
\hline 3 & $71-80$ & 8 & fail/pass \\
\hline 4 & $81-90$ & 0 & pass \\
\hline 5 & $90-100$ & 0 & pass \\
\hline
\end{tabular}

$\begin{array}{ll}60=10 \text { students } & 84=0 \\ 64=10 \text { students } & 88=0 \\ 68=8 \text { students } & 92=0 \\ 72=8 \text { students } & 96=0 \\ 76=0 & 100=0 \\ 80=0 & \text { mean: } 65,55\end{array}$

Table 1 provides information about the result of pre-test. The average of pre-test was 65,55.

It is depicted that the students had low score in finishing the assignment of reading comprehension in Conventional Way. Some students at class were not able to finish the reading comprehension test well.

Table 2. The result of reading test of cycle I

\begin{tabular}{cccc} 
No & Range of Score & Total & Information \\
\hline 1 & $50-60$ & 0 & pass \\
\hline 2 & $61-70$ & 4 & pass \\
\hline 3 & $71-80$ & 25 & fail/pass
\end{tabular}


JEASP

Journal of English for Academic and Specific Purposes

Volume 3 Number 2, December, 2020

\begin{tabular}{llll}
4 & $81-90$ & 7 & pass \\
\hline 5 & $90-100$ & 0 & pass \\
\hline
\end{tabular}

$\begin{array}{ll}60=0 & 84=4 \text { students } \\ 64=0 & 88=3 \text { students } \\ 68=4 \text { students } & 92=0 \\ 72=10 \text { students } & 96=0 \\ 76=5 \text { students } & 100=0 \\ 80=10 \text { students } & \text { mean: } 77,00\end{array}$

Table 2 shows data about the result of test after the implementation of Cycle 1, the students' average score was 77,00 . It depicted that the students had better score in finishing the assignment of reading comprehension through main ideas of paragraphs.

Table 3. The result of reading test of cycle II

\begin{tabular}{cccc} 
No & Range of Score & Total & Information \\
\hline 1 & $50-60$ & 2 & pass \\
\hline 2 & $61-70$ & 9 & pass \\
\hline 3 & $71-80$ & 14 & fail/pass \\
\hline 4 & $81-90$ & 8 & pass \\
\hline 5 & $90-100$ & 9 & pass \\
\hline
\end{tabular}

$\begin{array}{rl}60=0 & 84=4 \text { students } \\ 64=0 & 88=3 \text { students } \\ 68=2 \text { students } & 92=6 \text { students } \\ 72=9 \text { students } & 96=0\end{array}$




\section{JEASP}

Journal of English for Academic and Specific Purposes

Volume 3 Number 2, December, 2020
$76=2$ students
$100=0$
$80=10$ students
mean: 80,2

Table 3 provides data about the students' average score of cycle II $(80,22)$. It depicted that the students had better score in finishing the assignment of reading comprehension through main idea of paragraphs than those of the previous cycle (cycle I).

Table 4. The questionnaire related to the ways in comprehending the text

\begin{tabular}{|c|c|c|c|}
\hline \multirow{2}{*}{ No } & \multirow{2}{*}{ Name } & \multicolumn{2}{|c|}{ Reading Comprehension } \\
\hline & & Ordinary & Main Idea of Paragraphs \\
\hline 1. & Farah S. & $\sqrt{ }$ & \\
\hline 2. & Rei Amik & & $\sqrt{ }$ \\
\hline 3. & Ardha Okta & & $\sqrt{ }$ \\
\hline 4. & Rizki Nur L. & & $\sqrt{ }$ \\
\hline 5. & Sulis Setiyo & $\sqrt{ }$ & 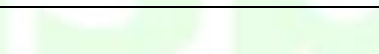 \\
\hline & Adin Erdian & & $\sqrt{ }$ \\
\hline 7. & Ainin Arif & & $\sqrt{ }$ \\
\hline 8. & Deni Purwo & & $\sqrt{ }$ \\
\hline 9. & Dhimas Adi & & $\sqrt{ }$ \\
\hline 10 & Frita Ferdina & & $\sqrt{ }$ \\
\hline 11 & Desi Yunita & $\sqrt{ }$ & \\
\hline 12 & Destanto & & $\sqrt{ }$ \\
\hline 13 & Linda Yunita & & $\sqrt{ }$ \\
\hline
\end{tabular}




\section{JEASP}

H. Volume 3 Number 2, December, 2020

14 Septi Peria V V

\begin{tabular}{llll}
\hline 15 & Yuda Tri & $\sqrt{ }$ \\
\hline 16 & Alfa Rindi & & $\sqrt{ }$ \\
\hline 17 & Arinta Novia & $\sqrt{ }$ & \\
& & & \\
\hline 18 & Denis Kholida & $\sqrt{ }$
\end{tabular}

\begin{tabular}{clc}
\hline 19 & Ersi Egi & $\sqrt{ }$ \\
\hline 20 & Fitria April & $\sqrt{ }$ \\
& & $\sqrt{ }$ \\
\hline 21 & Ihsan W. & $\sqrt{ }$ \\
& & \\
\hline 22 & Nugroho Eko & $\sqrt{ }$
\end{tabular}

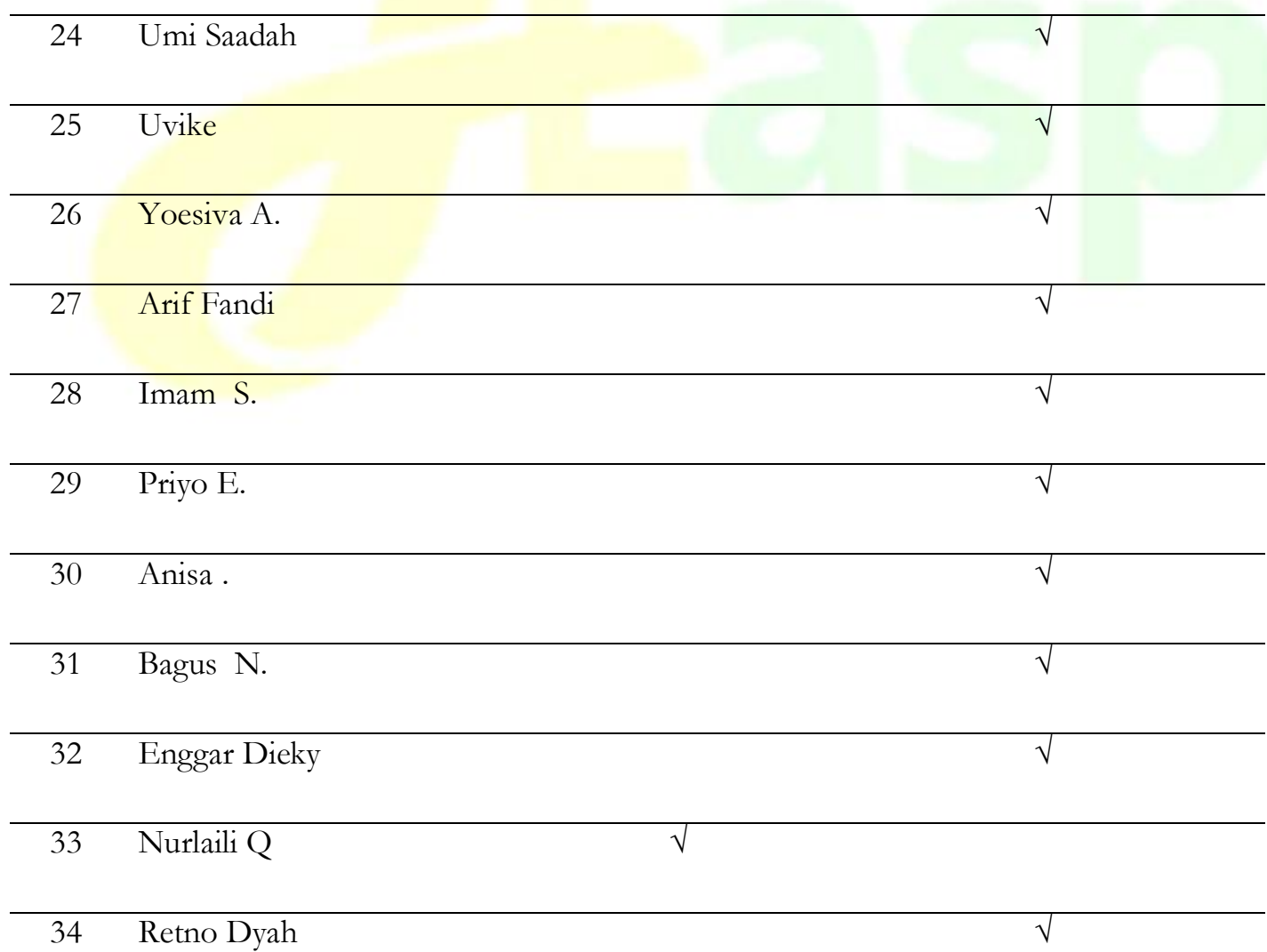


JEASP

II. Journal of English for Academic and Specific Purposes

Volume 3 Number 2, December, 2020

35 Yudhistira W.

$\sqrt{ }$

36 Evia Okta

$\sqrt{ }$

Table 5. The result of Questionnaire in Comprehending the text

\begin{tabular}{cccc}
\hline No & Number (1-36) & Ordinary Way & Main Idea of Paragraph \\
\hline $\mathbf{1}$ & $1-6$ & 2 & 4 \\
\hline $\mathbf{2}$ & $7-12$ & 1 & 5 \\
\hline $\mathbf{3}$ & $13-18$ & 2 & 4 \\
\hline $\mathbf{4}$ & $19-24$ & 0 & 6 \\
\hline $\mathbf{5}$ & $25-30$ & 0 & 6 \\
\hline $\mathbf{6}$ & $31-36$ & 1 & 5 \\
\hline
\end{tabular}

mean: 83,33

Table 5 provides data about the students' average score questionnaire $(83,33)$. It depicted that the students enjoy finishing the assignment of reading comprehension through main idea of paragraphs than one of the previous ways (Ordinary).

\section{The depiction of research}

Graphic 1. It shows the score of reading results of pre-test and post-test (cycle I and cycle II)

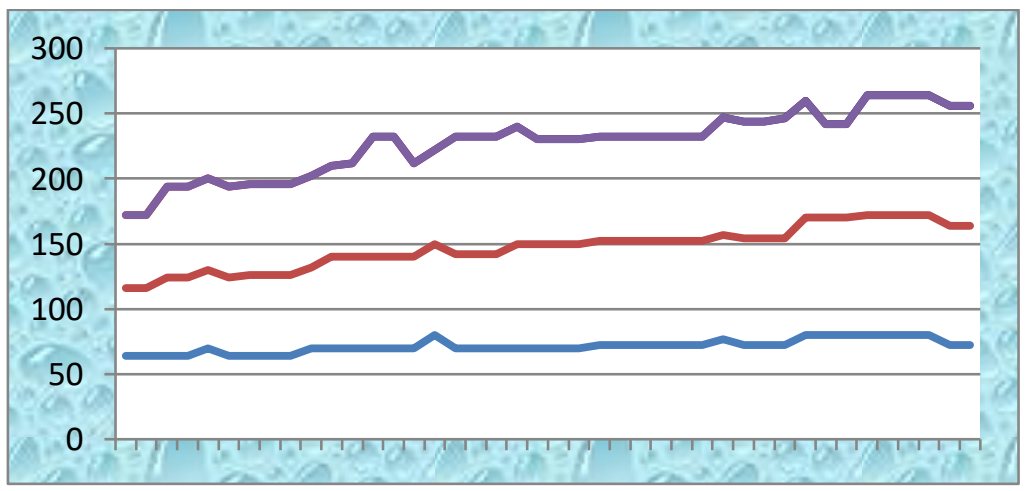




\section{JEASP}

Journal of English for Academic and Specific Purposes

Volume 3 Number 2, December, 2020

Note: blue (the score of pre-test) ; brown ( the score of post-test I); violet (the score of post-test II)

Graphic 2. It shows the result of students' responses on a questionnaire.

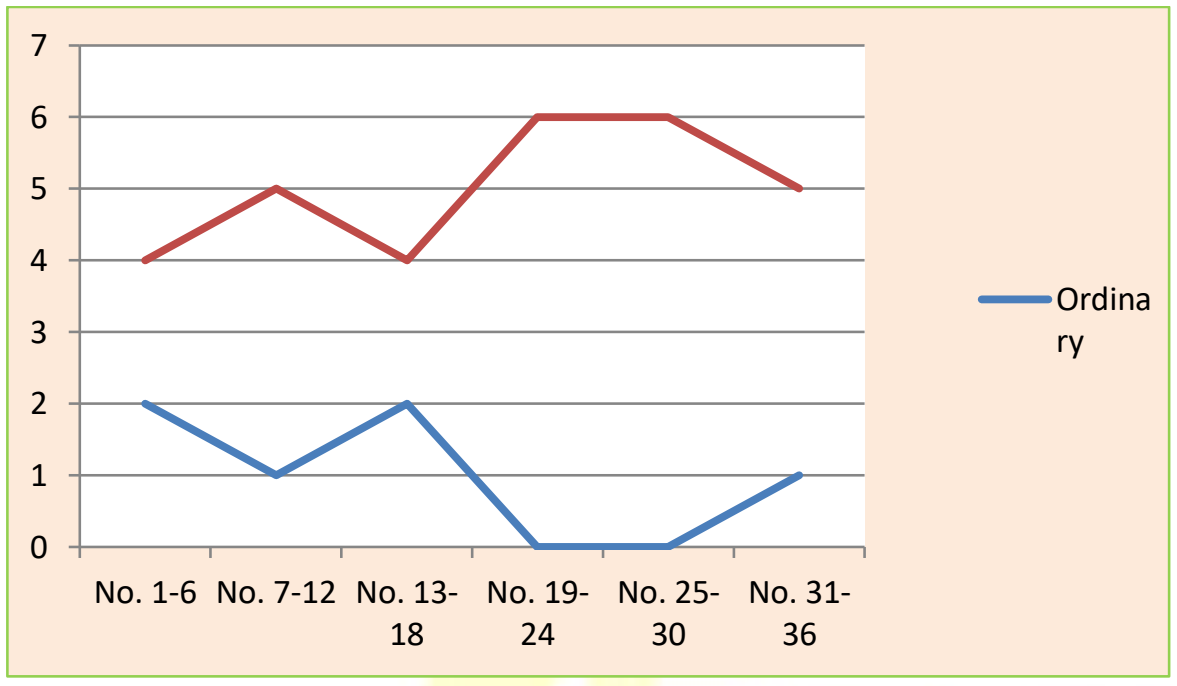

Note: blue (comprehending the text through ordinary way); brown (comprehending the text through main idea of paragraphs)

\section{DISCUSSION}

There are some theories that support how the students can increase their achievement in learning English, especially comprehending the passage It is really necessary to know that reading activity needs a specific way to comprehend the content of text One way is through understanding main idea of paragraphs (Nancy Arapoff, 1972: 200).

Smith and Robinson (1980, p.2018) state that in interpretative comprehension, "readers read between the lines and make connections among stated ideas, make inferences, draw conclusions or experience emotional reactions". Interpretative reading requires skills first, inferring main ideas of passage in which the main ideas are not directly stated. From the theories, it is clear that comprehending through main idea is one of the easier ways to practise the students' reading skill. Finding out the point information in a paragraph can be identified as the main idea. If the situation is often trained to students, they will be easier to grasp the text. The researcher's result data strengthen the theories. It shows that the students' achievement is increased by using main idea as a technique in teaching reading. Therefore, it can be used as a good way to motivate the students to learn better and 


\section{JEASP}

Journal of English for Academic and Specific Purposes

Volume 3 Number 2, December, 2020

they feel enjoyable to join at class because of the new way to motivate the students to learn better and they feel enjoyable to join at class because of the new way in reading comprehension.

According to Donn Byrne (1970: 3), It is true that comprehending the passage through main idea of paragraphs is able to help the students in reading activity. The way makes them to understand the passage more easily.

\section{CONCLUSION}

Based on the previous discussion, the following conclusion can be drawn. Comprehending the passage through main idea of paragraphs helps the students to understand the passage. This way is able to motivate the students in studying English, not boring to receive the reading material. To avoid the monotonous situation in a reading activity, the teacher must be creative to use variation of reading teaching techniques. One of the ways is through the main idea of paragraphs. The result of teaching variation, the students will be interested in listening the teacher's information, they are also able to grasp the reading material well. Beside that the students will be more creative to express the ideas in reading activity if they are often trained continuously with the way related to research.

Comprehending the passage through main idea of paragraphs gives significant benefit toward the students' capability in reading comprehension skill. Therefore, the way is acceptable to use in teaching learning process to avoid the students' boredom because of the same techniques in reading teaching learning process.

\section{REFERENCES}

Burn \& Joyce. (1999). The role of main idea of paragraphs in comprehending the text. (p. 25-30).

Don Byrne. (1970). Improving students' reading skill through parts of body paragraphs. (p. 90-100).

Fahrurrazy. (2012). Applying variation of reading techniques in reading skill. (p. 10- 20).

Jacob. (2015). Main Idea in Reading process in the EFL classroom. Fontys Hogescholen: Fontys Teacher Training College Sittard.

Richard \& Renandya. (2002). Applying variation of Reading Technique in Reading Skill. (Second Edition). Cambridge (p. 207-220).

Zamel. (1987). The teaching of Foreign Language in Indonesia (p.78-82).

Cowan, E. (1983). The Way of Teaching Writing. Ms Graw Hill International Book Company. 
JEASP

IDS Journal of English for Academic and Specific Purposes

Volume 3 Number 2, December, 2020

Levin, G. (1983). Short Essays, Model for Composition. New York, Harcout Brace Jowanovish, Inc.

Ozick, C. (1986). Teacbing Writing. (edited by Harold B. Allen). New York: Mc Graw Hill International Book Company.

Oshima, H. (1983). Writing with A Purpose. Arthur Koestler, New York: Hoghton Mifflin Company.

Tromklin, V. (2009). Writing Academic English. London: Addison-Wisley Publishing Company.

Rodman, Robert and Fromkin, Victoria. (1983). An Introduction to Language. Japan: CNS College, Publishing, Holt, Richard and Winston.

Zamel. (1987). Writing Task, An Authentic-Task Approach to Individual Writing Needs. Britain: Cambridge Press. 